\section{a Case illustrating The \\ DANGERS OF SLAUGHTERING DISEASED CATTLE.}

By JOHN GAMGEF, Esq.,

PROFBSSOE OF VETERINARY MEDICINE AND SURGRRY, NBW VETERINARY COLLEGE, BDTMBURGH.

ON the 22nd of October, 1863, a bull was taken ill on a farm and in a county which I decline to name. My reasons for not mentioning the place are, that every effort has been made to keep the secret, as in a host of similar cases, and it will serve no purpose whatever to expose those who, in ignorance and in consequence of the lax state of our laws on this subject, acted as their neighbours would have done. A labourer on the farm, who had been formerly a butcher, volunteered to slaughter the sick bull, that its carcase might be saved for the butcher's stall. Unfortunately, the poor man had previously injured his hand with a spade, and he performed his task without due regard to the condition of his wound. It is said that the bull was dying from pleuro-pneumonia, but others declare the disease was of too rapid a type to be the very prevalent lung complaint. Certain it is that four pigs died after eating part of the viscera of the bull, and two dogs nearly lost their lives in the same way.

The bull was disposed of to a butcher for the sum of $£ 5$, and after this, not only was it seen that the pigs and dogs had been injured by eating the flesh, but the labourer suffered intense pain in his:hand, was seized with severe febrile symptoms, and died on the fourth day after dressing the bull.

I am favoured by a surgeon with the following report of the case :-

"I saw the man for the first time on the second day before his death. I then found a ragged wound, about an inch long, nearly dividing the tendon of the back of the second finger of the right hand. The edges of the wound, for about threeeighths of an inch all round, were very much swollen and darkcoloured; in fact, the wound looked like an opening made with a blunt instrument. The swelling was well defined; there was also severe cellular inflammation of the arm to the elbow, with the usual boggy feel all over, from the back of the hand upward. Fever and the usual symptoms of severe cellular inflammation prevailed, notwithstanding tonics and stimulants. The man sank rapidly (the fever having turned to typhoid), and died on the second morning after I saw him. He was much addicted to habits of intemperance."

Many of the readers of THE LANCET may suppose that this is a solitary case, or, at all events, a rare one. The usual question may be asked, Why should $\mathrm{I}$, as a surgeon of so many years' experience, not have heard of or seen such cases? To my own knowledge, four other men have died, presenting symptoms such as the above, under similar circumstances and in the same county, during the last four years. Another man, a butcher, nearly lost his life, and the surgeon who attended him asked him what he had done with the diseased cattle he had dressed. This question was asked as the surgeon feared that the carcases were at that time being cut up in the town where they had been slaughtered; but he was somewhat consoled by the usual reply, "They're been sent to London."

During the past year the attention of a number of gentlemen has been directed to cases of serious illness and death in various parts of the country. A landed proprietor wrote me concern. ing an instance in East Lothian. An animal was slaughtered, packed in a basket, and sent either to Edinbrargh or London. After the carcase had been despatched, the pigs were taken ill, and several died; they had eaten of the animal's entrails. The man who dressed the bullock nearly lost his life, and only recovered after nearly losing his ey esight. Some liquid from the thorax was splashed against this man's face, and he suffered severely from inflammation of the face and trunk. His eyes were most seriously affected, and vision has only been restored in one.

In the Edinburgh slaughter-houses similar accidents have been witnessed, though every effort is made to conceal the truth; and one case, which occurred in 1863, was identical with the one that occurred in East Lothian. During the outbreak of malignant anthrax in Lincolnshire last autumn a shepherd scratched his arm whilst dressing a sheep, and he very nearly lost his life.
It is now about fourteen years since I first began to agitate the question of cattle disease in relation to the public health. During that time I have reported outbreaks of anthrax and of splenic apoplexy, and have repeatedly drawn attention to the deaths amongst pigs, dogs, ferrets, \&c., from eating the viscera of diseased cattle slaughtered. I have striven, as best I could, to specify the form of disease communicable to man, and which renders the flesh of such animals unwholesome; and my opinion, based on a very careful consideration of the whole subject, is, that the public health is materially affected by the wholesale slaughter of diseased animals as human food. Several years ago I declared that it was impossible that human beings were not fre. quently injured by the eating of the flesh of cattle that had died of splenic apoplexy in this country; and the reason why cases have not been published is, that the carcases have been sent to large cities, where they would not be distinguished from the carcases of perfectly healthy animals, and the evil results of eating the poisonous flesh could not be distinguished from any ordinary case of dysentery or typhus. The best proof of de. fective observation on these subjects is afforded us by the trichinous disease, of which not a single fatal case has been re. corded in this country, but many abroad. That the disease is often amongst us is certain, and the infant that died in Paisley last year, as the result of eating "measly (?) pork," undoubt. edly, in my mind, succumbed to trichinous infection.

Knowledge gathers slowly, and medical men must proceed with prudence in drawing inferences from cases observed; but I hold that they have hesitated too much and too long in rais. ing their voices against the filthy and demoralizing practice of slaughtering diseased animals as human food. With a proper organization, I will engage to reduce the mortality in the London dairies from forty and fifty per cent. per annum to four and five. This would at once prevent the sale of several thousand diseased cows as human food in the metropolis alone. Would not such work be better worth paying for than inspection of markets? and is it not worthy of the strongest recommendation on the ground of economy, if not on that of saving human life? We "strain at a gnat and swallow a camel" when we condemn the French for their vivisections, and allow our population to be cut down in thousands by painful and preventable diseases. On no ground can we defend the slaughter of diseased cattle, and medical officers of health need not wish to be fortified by evidence of cases of death in man from eating diseased meat in order to interfere vigorously with the traffic in diseased animals. That traffic is the most potent cause of disease in animals themselves, and unless checked our stockowners will suffer even more in the future than they have in the past. We cannot keep pace with the demand for meat, and prices are ruling higher every year. To secure an adequate supply of wholesome animal food we must devote ourselves to the prevention of disease amongst animals, and no greater blunder was ever committed than that of declaring that our poor must starve if we condemn all the diseased animals sent to the butcher. The poor may console themselves a little by the refiection that it is the finest cattle in the best condition that usually die of splenic apoplexy, and the accidents which befel the pigs and ferrets from this cause are more likely to be witnessed in the homes of the wealthy than in those of people who cannot afford to pay the highest market price for beef.

\section{THE MURDER NEAR LEOMINSTER.}

\section{REPORT OF THE INJURIES AND OF THE POST-MORTEM} EXAMINATION OF THE DECEASED.

\section{By EUGENE GODDARD, M.R.C.S.E.}

MARY ANN WATKINS, the wite of a deserter from her Majesty's service, was found about ten P.M. on the night of the 18th ult. lying on her face in a pool of blood, insensible, and with several gaping wounds in her head. She was placed in a cart and brought to the Leominster Union Workhouse, where I was called to her at a few minutes to one A. M., and attended directly. She appeared perfectly unconscious; the surface and extremities were cold; the pupils insensible to light and moderately contracted; respiration comparatively quiet, but slow; pulse scarcely perceptible. On examining the head I saw a small clean wound, about an inch long, in the median line, just above the forehead; a second, about six inches long, also having a smooth edge, extending across from the upper poste- 
rior angle of the right parietal bone to the squamous portion of the temporal bone, and exposing a gaping fracture of the skull, through which brain-substance was protruding, and portions of pericranium were hanging down in bruised and torn strips. Posteriorly there was a wound eight inches long, extending in a curved direction over the upper part of the occipital bone and the posterior inferior angle of the right parietal as far as about the base of the zygoma, exposing a comminuted fracture of these bones in the same direction as the wound. There were some fragments of brain-matter about her hair and a neckerchief which she wore, and I had observed some about the straw of the cart in which she was brought to the workhouse. Altogether, her symptoms promised a speedy death. Nevertheless I gently removed the hair, cleaned the wounds, and applied cold to the whole of the head. Meantime, hot bottles had been placed at her feet, she had been partially undressed and wrapped in blankets, \&c. By daylight reaction had set in, and with it symptoms of compression; the breathing became stertorous; the pulse perceptible but small, and about 30 or 32 ; the surface hot; the pupils slightly dilated. Two or three teaspoonfuls of beef-tea were administered with difficulty during the day, and in the afternoon she was reported to have said "Oh dear!' twice. She never became conscious, however, and died at nine o'slock in the evening, twenty hours after admission.

Thirty-six hours after death I made a careful post-mortem examination by order of the coroner, and was assisted by my friend and colleague, Mr. A. G. Chattaway, of Kingsland, near Leominster.

External appearances: She was a well-conditioned, healthylooking woman. There was a bruise over the right frontal protuberance; both eyelids ecchymosed; a swelling of the upper lip, and a slight abrasion from the right corner of the mouth; a short straight contusion on the right shoulder; a large patch of bruise on the upper part of the right arm; sundry small scratches and bruises on both wrists; trunk and legs free from marks; opisthotonos considerable.-Head : In addition to the wounds already described, there was an irregular jagged wound, two inches long, over the left parietal eminence. The posterior wound presented these peculiar appearances: its lower edge was jagged, its upper tolerably smooth; in the centre it gaped about an inch, and there was a good deai of hair pushed in over its lower edge, some score or so of hairs being found between the fractured pieces of bone, and adherent to the brain-substance. On carefully dissecting off the integument, pericranium, \&c., the occipital bone was observed to be much comminuted, whence the fracture proceeded in a somewhat star fashion in two or three directions round the right side of the head, some of these lines communicating so as to detach two large and two or three small pieces of the calvaria, while a single fine line of fracture extended from these across the coronal suture to the centre of the frontal bone. In addition to these, there was an isolated oval fracture about the size and shape of a pigeon's egg immediately beneath the small and apparently incised wound first mentioned. The brain and membranes were healthy; a good deal of the right hemisphere was destroyed and absent, probably three or four ounces; normal amount of fluid in the ventricles. - Chest and abdomen: With the exception of some pleuritic adhesions and a small multilocular cyst attached to the right ovary, there was no trace of disease in any organ of the body.

In endeavouring to account for these injuries, I was struck by the appearance of the posterior wound, the upper edge projecting beyond the lower, the lower edge being jagged and turned in, \&c. It seemed clearly to have been caused by a blow from below upwards-probably a kick. This, I think, is supported by the fact that the wound exposed a comminuted fracture of the strongest part of the skull. The anterior wound, with its little island of fracture beneath, and the middle wound, with its sharply-defined fracture, were not so clearly to be accounted for.

On the $20 \mathrm{th}$ ult. I visited the spot where the body was found. It was in a ploughed field, and there was no stone or rock or hard surface anywhere about. I may here state that the police observed some remarkable footprints about the field and in an adjoining orchard; that they followed these tracks for many miles over the country during the next three days; that on the evening of the third day they overtook the husband of the deceased, with " clogs" on his feet perfectly correspond. ing with the footprints they had been tracking from the scene of the tragedy. These clogs were produced at the inquest and before the magistrates; they were of the shape of an ordinary boot; the sole and heel were of wood about three quarters of an inch thick, bordered entirely by a narrow rim of iron some. thing like the bottom of a skate. I stated at the inquest and before the magistrates that such a boot would probably account for the posterior fracture, and also, but less probably, for the other wounds and fractures. The short straight bruise on the shoulder looked as if it had been caused by a stick, and evidence of the prisoner having been seen with a stick on the day of the murder was subsequently produced. On this evidence, substantiated by proofs of his having uttered violent threats against his wife, the man stands committed to take his trial for wilful murder at the next Hereford assizes, It is to be hoped that, if guilty, he will by a full confession enable us to see how far the conclusions arrived at from the nature of the injuries are accurate, as this would tend to show the value of such inferences in any similar case.

Leominster, Feb. 1864.

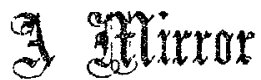

OF THE PRACTICE OF

\section{MEDICINE AND SURGERY IN THE}

\section{HOSPITALS OF LONDON.}

Nulla autem est alia pro certo noscendi via, nisi quamplurimas et morborum, et dissectionum historias, tum aliorum, tum proprias collectas habere, et inter se comparare.-Hongagri De Sed. et Caus. Marb., lib. iv. Procmium.

\section{ST. BARTHOLOMEW'S HOSPITAL.}

SUBCUTANEOUS MELANOSIS, SCATTERED OVER THE TRUNK AND EXTREMITIES, THE " TUBERCULATED SARCOMA"

OF MR. ABERNETHY.

(Under the care of Mr. LAwRENCE.)

There is a rare and somewhat remarkable case at the pre. sent time in the above hospital, and which is deserving of an early notice before it reaches a final and fatal termination. It is an example, Mr. Lawrence remarked at the patient's bedside, of the "tuberculated sarcoma" of Mr. Abernethy, described by that surgeon many years back, and of which he (Mr. Lawrence) had himself seen but one other example.

The patient, James F___ aged thirty-three, a porter, thin and emaciated, was admitted on the 28th of January, stating that he had been ill since a week before Christmas. Some eighteen months ago small nodules or grains began to form on various parts of the abdomen, which gradually extended to the chest and posterior part of the trunk of the body. Some are now appearing on the inner side of the arms, especially the left; but the trunk and upper extremities are the parts chiefly affected. Emaciation has been rapid quite recently, his appetite has failed, and he feels weak and debilitated and has a peculiar look of anguish and misery. He does not appear to suffer any pain except in the loins. The nodules are mostly small, in size from a millet-seed to a pea or a bean, and seem to be situated beneath the integument in the subcutaneous areolar tissue, although it is probable that some, possibly a large number, may have already invaded the skin. Throngh the skin they possess a distinct blue colour, like knobs on veins, and at first sight they look as if all the cutaneous veins were knotted here and there. At the right groin is an irregular mass, the size of a small Seville orange, very soft and spongy, and apparently not an involved gland. The man has latterly commenced to pass blood in his urine, which, taken with a pain or soreness in the loins, would point to a probable extension of the disease not only to the kidneys, but very likely to other internal organs. His breathing a fortnight ago was hurried and rapid, as if a similar invasion of disease was taking place in the lungs. He is well supported by good nourishment and plenty of stimulants, and the treatment is palliative, for the disease is incurable.

There can be no doubt that the disease is disseminated mela. nosis, associated either with scirrhous or encephaloid cancer, and analogous to the secondary growths of a malignant nature appearing in varions internal organs. This form of disease is accurately noticed in Dr. Walshe's monograph on Cancer, under the division of the disease involving the subcutaneous cellular tissue. In the great majority of cases, be states, the structure of the nodules has been encephaloid, although 